\title{
Long Term Consumption of Ibie Leave (Mucuna Flagellipes) Diets Improves Visuo- Spatial Learning and Memory in Swiss White Mice
}

\author{
Amah, A.K. ${ }^{*}$, Aduema W' ${ }^{2}$ Arisa, $\mathbf{U}^{3}$, Ejiofo, D.C ${ }^{1}$ \\ ${ }^{1}$ Department of Medical Physiology, Imo State University, Imo State, Nigeria \\ ${ }^{2}$ Department of Human Physiology, PAMO, University of Medical Sciences, Port Harcourt Rivers State, Nigeria \\ ${ }^{3}$ Department of Human Physiology, Gregory University, Uturu, Abia State, Nigeria
}

*Corresponding Author: Amah, A.K, Department of Medical Physiology, Imo State University, Imo State, Nigeria

\begin{abstract}
Abs tract: Mucuna flagellipes is one of the plants commonly used widely in the South Eastern part of Nigeria for the treatment of Anemia. There have never been any record authenticated to the best of my knowledge that focus on the effect of Mucuna flagellipes on visuo-spatial learning \& memory, therefore the objective of this study was to determine whether Mucuna flagellipes has effect on the above neurobehavioral parameter, using CD-1 as experimental animals. Thirty CD-1 mice were bought and randomly divided into two groups, consisting of ten (10) mice. Group 1(control) received normal rat fed whereas group 2(test) received the Mucuna diet and clean drinking water for twenty-one days. After this period, they were tested using the Morris water maze. The group 2 animals that received the Mucuna flagellipes showed improved learning and memory behavior by a significantly lower swim latency during acquisition training and reversal training $(P<0.01)$ and $(P<0.05)$ compared to group 1 (control). Preference to the Northwest and Southeast quadrant was statistically higher $(P<0.001)$ compared to group 1.Annulus reversal crossing was also higher $(P<0.01)$ when compared to group 1. In visible platform task, the test group was statistically lower $(P<0.001)$ compared to $g$ roup 1 . Therefore, Mucuna flagellipes with a fair measure of accuracy improves learning and memory and could be used in the management/ treatment of retrograde amnesia.
\end{abstract}

Keywords: Mucuna flagellipes, Morris Water Maze, Memory, Mice.

\section{INTRODUCTION}

The system of use of plants for food and drug dates back to the early man on earth (1). The use of natural products with medicinal properties for chronic and acute diseases is as old as human existence (2) long ago, animal products, plant and mineral are the main sources of medicine (3), (4). About $40 \%$ of the population of the technologically and economically advanced countries like the U.S.A, U.K, still makes use of alternative remedies, including herbal medicine for disease prevention and cure (5). In addition, compounds Plant based medicine has over time become man's prime therapeutic weapon and still is as seen in its continued use in treatment of diseases up till today (6). All over the world, humans have used a variety of numbers of native plants in the cure of diseases since prehistoric times $(7,8)$. There is hardly any person who does not take herbal remedy daily in one form or the other. This is true as reports by (9) revealed, in anyone who eats vegetables, takes medicinal herbs, be it lettuce and spinach in Sumerians who described well established medicinal plants as laurel caraway and thyme. Also the Chinese herbal book dating from about 2,700 BC listed medicinal plants and their uses (10).Many cultures have used different types of plants or materials derived from them in preventing and treating diseases through history (11).Its efficacy is justified by its continued use. It is for the development of modem chemistry that has led to the discovery and identification of the materials in plants that serves as drugs or basic material for the synthesis of many important drugs used today. These drugs been synthesized from the knowledge acquired from studies of the mechanism of chemicals and their actions first separated from herbs. Thus researchers in medicinal herbs have increased in order to ascertain their chemical compositions which are medicinally active. Mucuna flagellipes which is commonly called cow itch and locally called Ibie. There are abundance of macro elements like calcium magnesium and iron (12). The pod hairs have been used in India to treat snakebite (13), while in West Africa; it is the 
stem that is used for treating of snakebite (14). Their stems have been reported to also improve sexual potency $(15,13)$. Its pods have also been used to deworm patients $(16)$. The modus operandi of the pod hair is mechanical, thus when mixed with substances like honey, pierces the bodies of the intestinal worms, twisting such that catharsis will push them out. Although it is seen to have little effect on tape worms $(17,18)$. The leaves supply a proteinous fodder for livestock's while the nodules play an important role in nitrogen fixation in the soil $(19 ., 20,21)$. The stem is also used for tying seeds in the bam and yield black dye. The use of Mucuna flagellipes in recent time has been on the increase as a result of its speculated therapeutic effect mostly on the protein level of the body (22). And owing to the fact that there are no detailed reports on Mucuna flagellipes or from the best of my knowledge any study or report on its effect on learning and memory, this work is therefore intended to determine the effects of this herb on the learning behavior and memory of Swiss white mice.

\subsection{Animal Care}

A total of twenty healthy CD-1 mice weighing 20-22grams were used for the study and the mice were bought from the Department of Pharmacology of Michael Okpara university of Agriculture, Umudike Nigeria. The mice were kept in a clean and well ventilated compartment and fed with normal rodent fed and allowed access to water ad libitum for fourteen days to allow acclimatization before the commencement of the experiment.

\section{Experimental Design}

Dried pulverized Mucuna flagellipes was mixed with the rodent chew at a proportion of 30grams of the powdered leave and 70 grams of the rodent chew. The Swiss mice were divided into two groups, namely: Group 1 and Group2. The group 1 was the control which received 50grams of rodent chew and $60 \mathrm{ml}$ of water daily while the group2 was the test group that received 50grams of the mixed leave and rodent chew, with $60 \mathrm{ml}$ of water daily. Analysis of the phytochemical composition of the leaves of Mucuna flagellipes was done following the methods outlined by Trease and Evans (23) for the presence of Alkaloid, saponins, glycoside, carbohydrates, flavonoids, tannis, and protein.

\subsection{Ethical Approval}

The principle of Laboratory animal care was followed. All animals have been examined and approved by the appropriate ethics committee.

\subsection{Procedure}

During the acquisition training, the water was adjusted appropriately such that the platform was placed in the center of the northeast quadrant. Each animal received 4 trials of 60 seconds (max) per day. The starting position was predetermined, which prevented 2 trials from being repeated by the same animals during other days. Start positions were located at the boundaries of each quadrant. Each mouse was removed from its holding using a small, clean 70cl plastic container to minimize stress.

The animal was placed into the water at the appropriate start position, facing the center of the pool. The mouse was then permitted to explore the pool and to search for hidden escape for 60 seconds. When the animal located the platform the timer was stopped and the animal was removed from the plastic container and placed into the holding cage. Once in the platform the mouse was permitted to visually explore their surrounding for 20 seconds at which point, they were picked up and placed on their appropriate holding cage. The next mouse was then placed in the pool and same procedure was repeated. Each mouse completed 4trials per day over 3days. This amounted for 12 trials for acquisition training.

Reversal training period began on the $4^{\text {th }}$ day. The invisible platform was moved to the opposite quadrant (Southwest) and mice were again assigned to appropriate start position. The same procedures as in acquisition training were carried out during the reversal training. Each of the animals completed 4 trials per day for 3 days for a total of 12 trials for reversal training.

A probe trial was conducted at day 7. At this time, there was no escape platform in the maze. Each animal completed one trial of 60 seconds. Each animal was placed in the maze from one of the four possible positions and allowed to explore the pool. The duration in each quadrant and the frequency of entry form the northeast and southwest quadrants was noted. 
The visible platform task was conducted on day 8 . The visible platform was placed in the Southwest quadrant of the pool. The same procedure as in acquisition training and reversal training was carried out and mice completed 4 trials.

\subsection{Behavior Scored}

The behaviors scored during the Morris water maze were in acquisition training and reversal, visible platform test. These include:

Swim latency (time taken to locate and mount the platform)

Whereas during the probe trial, the duration in each quadrant were recorded (NE, SE, NW, and SW) including the annulus acquisition crossing (i.e. the number of times the mouse crosses the location of the platform during acquisition training) and annulus reversal crossing (i.e. the number of times the mouse crosses the location of the platform during reversal training).

\subsection{Statistical Analys is}

The values were expressed as mean and \pm SEM (standard error of mean). Hypothesis testing method includes one way analysis of variance (ANOVA) followed by post hoc performed with least significant difference (LSD) dunnett. P.value of less than 0.05 was considered to indicate statistical significance and 0.001 as highly significant respectively.

\section{RESULTS}

\subsection{Behaviours Scored in the Morris Water Maze}

\subsubsection{Acquisition Training}

On day 1, the swim latencies obtained showed that mice, fed with control and Ibie leave diets, scored $163.75 \pm 16.31$ and $110.75 \pm 14.20$ seconds respectively. In day 2 , the swim latencies were $73.50 \pm 6.50$ and 56.00 \pm 3.34 seconds for mice fed with control and Ibie leave diets. For day 3 of the acquisition training, the swim latencies were $92.25 \pm 13.57$ and $60.00 \pm 2.70$ seconds for mice fed with control cooked and Ibie leave diet. The swim latencies for the Ibie leave group was significantly lower compared to the control group during the 3 days of training. This is as shown in figure. 1

\subsubsection{Reversal Training}

On day 1 , of the reversed training, the swimming latency for mice fed with control and Ibie leave diet were $99.75 \pm 4.76$ and $50.75 \pm 13.75$ seconds respectively. During the second day of reversal training, the swimming latency was $56.25 \pm 8.36$ and $26.50 \pm 3.22$ seconds for mice fed control and Ibie diet. For day three (3) of the reversal training, the swimming latency was $53.75 \pm 6.53$ and $35.50 \pm 3.61$ seconds for mice fed with control and Ibie leave diet.The swim latencies for the lbie leave group was significantly lower during the reversal training (figure 2$)$ compared to the control $(\mathrm{P}<0.01)$. However, the Ibie leave group was also significantly shorter $(\mathrm{P}<0.05)$ compared to control group.

\subsubsection{Retention Quadrant}

Figure 3, compares the quadrant duration during the probe trial in the Morris water maze between the two experimental groups of mice which were, $12.90 \pm 0.17$ and $28.52 \pm 2.63$. The duration of stay in each quadrant is shown in figure 4.1.3. During the trial, the two groups had more preference to the North-west and South-East quadrant (that bears the platform during the reversal training when compared to control). The preference to the NW and SE quadrant for the mice fed with Ibie diets was signific antly higher $(\mathrm{P}<0.001)$ compared to control.

\subsubsection{Annulus Acquisition \& Annulus Reversal Crossings}

Figure 4, compares the annulus acquisition and reversal crossings during the probe trial task. The values for the annulus acquisition crossings are $23.75 \pm 3.35$ and $51.66 \pm 12.57$ seconds for mice fed with control and Ibie diet respectively. The values for the annulus reversal crossings are $20.75 \pm 0.85$ and $35.00 \pm 4.26$ seconds for mice fed control and Ibie diet. There was no significant difference among the groups in the annulus acquisition crossings. For the annulus reversal crossings, as shown in figure 4 , the Ibie leave group was significantly higher compared to control $(\mathrm{P}<0.01)$. 


\subsubsection{Visible Platform Task}

The swimming latency in the visible platform task was $56.25 \pm 2.39$ and $32.00 \pm 2.85$ seconds for mice fed with control and diet. During visible platform task, the swim latencies of the Ibie group was significantly lower $(\mathrm{P}<0.001)$ compared to control. Figure 5.

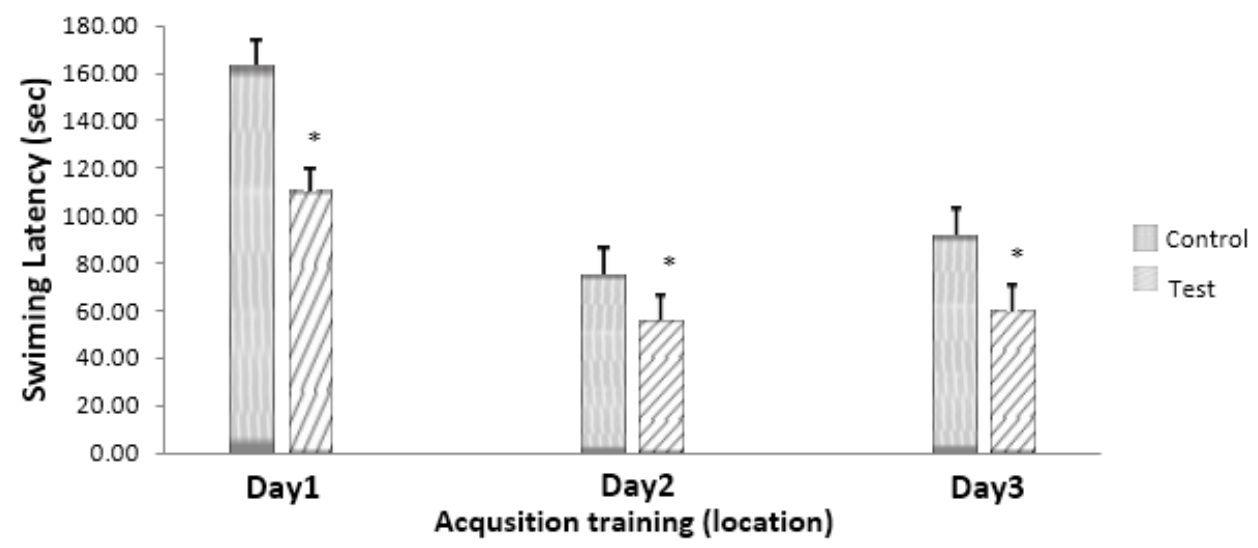

Fig1. Swimming Latency during the acqusition training among the different experimental groups recorded at day 1 , day 2, and day 3, in in morris water maze training tes. Values are expressed as mean $\pm S E M, n=9$;

$*_{p}<0.05$ vs control

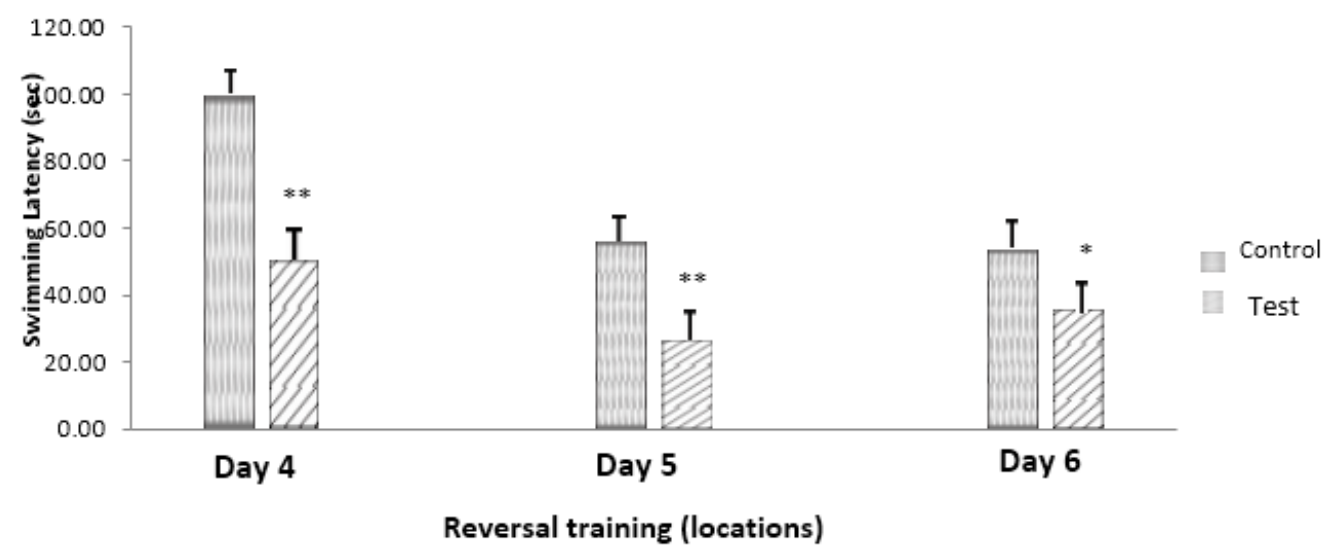

Fig2. Swimming Latency during the reversal training among the different experimental groups recorded at day 4 , day 5 and day 6 , in morris water maze training test. Values are expressed as mean $\pm S E M, n=9$;

$* * p<0.01$ vs control,

$* p<0.05$ vs control

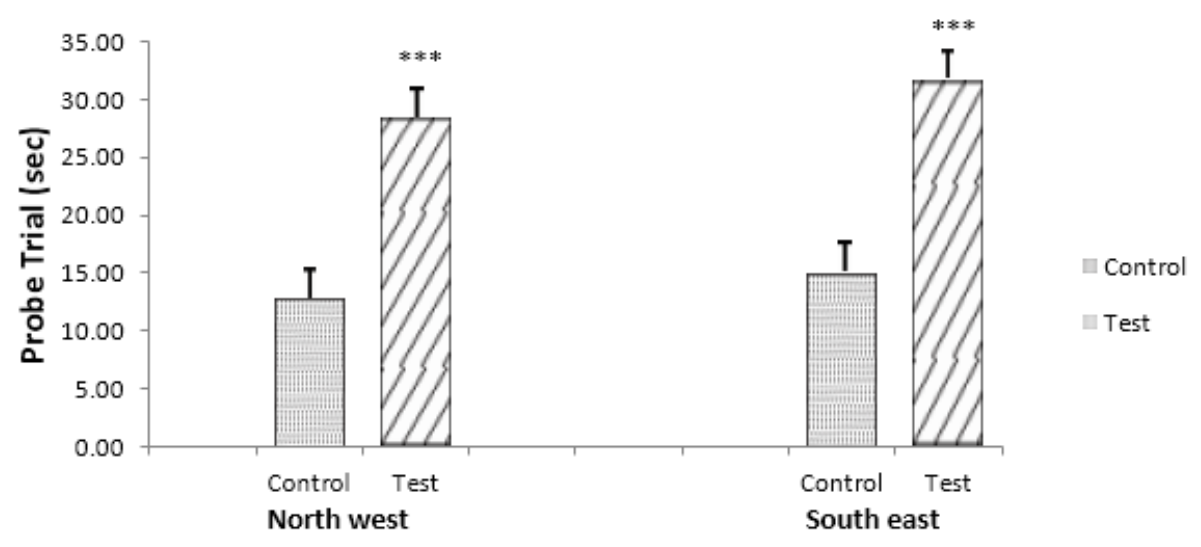

Fig3. Retention Quadrant during the Probe Trails recorded at day 7 among the North west and south east in the different experiment groups during the Morris water test. Values are expressed as meam $\pm S E M, n=9$;

$* * * p<0.001$ vs control 


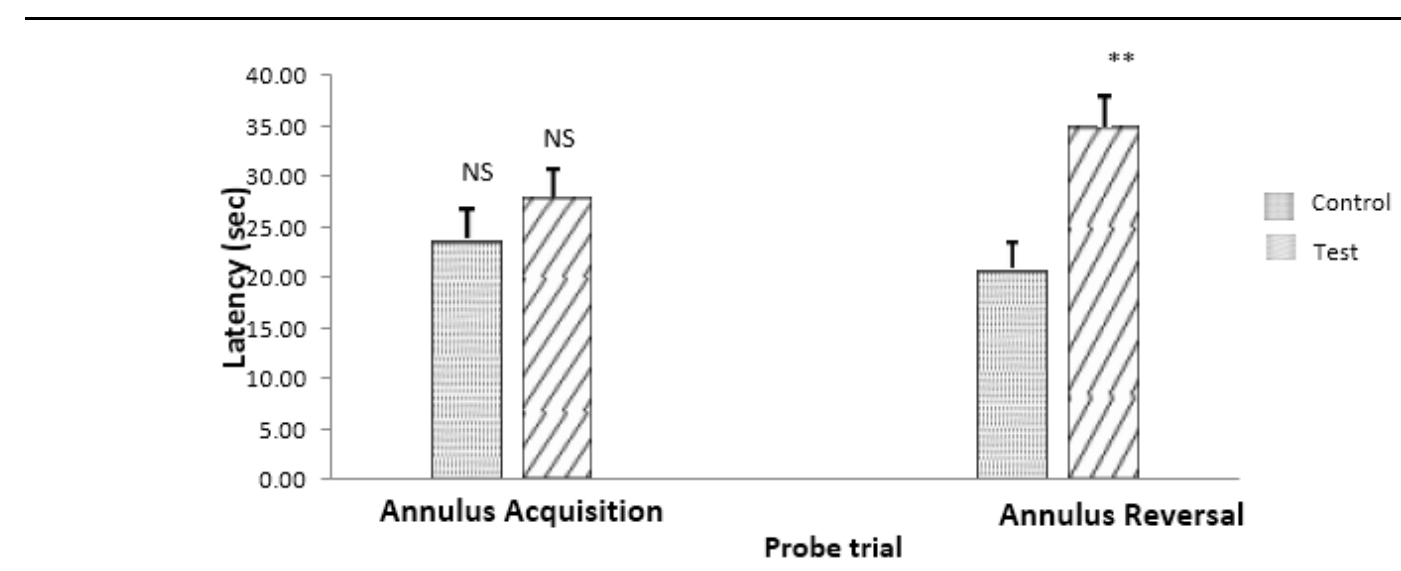

Fig4. Annulus Acquisition and reversal recorded at day 7 among the different experimental group during the Morris water maze test. Value are expressed as mean $\pm S E M, n=9$;

$* * p<0.01$ vs control

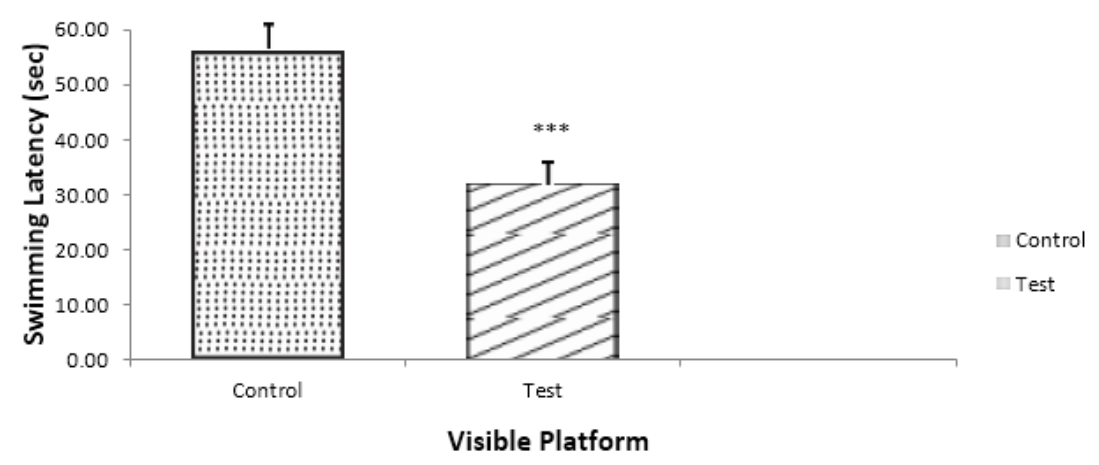

Fig5. Visible platform among the different experimental groups recorded at day 8 in the Morris water test. Values are expressed as meam $\pm S E M, n=9$;

$* * * p<0.001$ vs control

\section{DiS CUSSION}

Morris water maze was employed as a behavioral model for evaluation of learning and memory in mice. This model is widely employed for assessing the effect of drugs on learning and memory (24). The results showed that increase in swim latency during acquisition training period as shown in fig 1 shows that the Ibie leave fed mice which were the test group, learnt faster mounting the escape platform as compared to the group not fed with Ibie leave (control).Similarly, in the reversal training, the test animals takes less time in locating the escape platform compared to the control. The experimental animals had more preference in the Northwest and Southeast (NW and SE) in the retention quadrant during the probe trial. Thus indicating that these treated animals remembered the position of the escape platform located in the NW and SE quadrant compared to the control group, thus increasing their frequency to these quadrants for escape as compared to the control. The result justifies that their memory were improved as compared to control group that had lesser preference to the retention quadrants. In the visible platform task, the test animals still showed shorter swim latency compared to their control group, suggesting that they have better memory. It has been reported that flavonoids have effect on memory and cognition. Although many studies in the field have been performed with flavonoid-rich foods, both these studies and studies with isolated flavonoids have potential to activate synaptic signaling and ability to improve cerebrovascular blood flow thus improve memory (25). Studies with fruit supplements indicate that flaanols, tlavanones and anthocyanidins which are derivatives of flavonoid have the capacity to improve memory (26).

Emerging evidence suggests that dietary-derived flavonoids have the potential to improve human memory and neuro-cognitive performance via their ability to protect vulnerable neurons, enhance existing neuronal function and stimulate neuronal regeneration (Jeremy P.E.Spencer 2008). Therefore, flavonoid which is one of the major constituent of the Ibie leave may be responsible for the learning and memory enhancing activity exhibited by the experimental animal (mice). 
Long Term Consumption of Ibie Leave (Mucuna Flagellipes) Diets Improves Visuo- Spatial Learning and Memory in Swiss White Mice

\section{CONCLUS ION}

The Ibie leave (Mucuna flagellipes) have been proven to have learning and memory enhancing effect. Therefore, the Ibie leave can be recommended for its good therapeutic efficacy for improving learning and memory, if it is extrapolated to humans.

\section{ACKNOWLEDGEMENT}

The authors wish to acknowledge the assistance of Mr. Oreabosi Michael in collection of the sample and Mr.Uchenna who help in the laboratory analysis.

\section{Author CONTRIBUTION}

All authors have contributed one way or the other to the success of this paper and there is no conflict of interest.

\section{REFERENCES}

[1] Okafor J.C (1998) some useful tropical plants in health care delivery. Guest lecture Delivered at the 6th annual general meeting of the Nigeria society of pharmacognosy of 12 commonly used medicinal herbs. Archives of Family-Medicine. 7, 523-536.

[2] Borris, R.P., 1996. Natural products research: perspectives from major Pharmaceutical Company. Journal of ethnopharmacology, 51 (1/3), 29-38.

[3] Drew, T (1993). Motor cortical activity during voluntary gait modifications in the -fnrplimhs. Journal of Neurophvsiology, 70:179-82.

[4] Rates, S.M.K. (2001). Tuvin, 39: 603-13.

[5] Elsenberg, D.M Davis, R.B; Appel, S. Wikey, E. Von Ram. Pay, Kessler M.R.C (1998). Trends in Alternative Medicine in the United States Journal of American Medicinal Association. P. 100-116.

[6] Turrow V. (1998): Herbal therapy for children. Pediatrics 102:1492-1493.

[7] Wild R., (Ed) (1994): The complete book of natural and medicinal cures. Rodale Press, Inc. Emmanus Pennyslvania.N.Y.

[8] Bangori, D. (2003) what is traditional medicine world. World health organization (WHO) Media - centre. Evidence and mechanisms of action. Nutrition, 130:2127-2130.

[9] Kafaru, (1994).Cognitive function: a cross-sectional study from the Tsurugaya Project 1. American J Clin Nutr 83,355-361.

[10] Kains M.G (2007): Guterbery book of culinary herbs, their cultivation, harvesting and curing uses. Macmillana New York. NY.pp:12-23.

[11] Abbiw, D. (1990). Useful plants of Ghana Intermediate Technology. Botanical Garden Kew. pp. 337.

[12] Rajaman, N. and Jonardhaman K. (1991). The botanical composition and nutritional potential of the tribal pulse, Mucuna gigants (wild) DC plant food for human. Nutrition (4): pp.45-51.

[13] Siddhuragu P.K, Vijiayakumari and Jonardiam K. (1996): Chemical composition and protein quality of little known legumes velvet (LDC). Journal of Agricultural and food chemistry, 44:2636-2641.

[14] Houghton .J. (1994); Flora of West Africa. Vol. 1. Longman. Pp.10-15.

[15] Thompson, W (1978): Medicine from the earl company Maiden head, United Kingdom. McGraw-Hill book.

[16] Faridah Hanum, I, and Van der Maesenh J. (eds) (1996). Prosea handbooks No 1, auxiliary plants pros seal Bogor, Wagering. Netherlands pp. 16-17.

[17] Murray, V.R. and Johardhaman (1995); Chemical analysis and nutritional assessment of lesser known plants of the genus, Mucuna, Food chemistry 52:275-280.

[18] Grieve M. (2006); A modern herbal home. Www.botanica.com. Pp.6-10.

[19] Nwude, N. (1986).Veterinary aspect of Medicinal plant. - Macmillana New York. NY.

[20] Okolo M; Unaiqual JE (1984). Herbal medicine: selected or potentiating herb interaction. Archives of internal medicine, 158:2200-2211.

[21] Lesile S. Cobley (1985). Introduction to the Botany of tropical Crops. K. Longman Green and Co. Limited. Gros venar Street London pp.48-56.

[22] Farogi, A.A, Khan M.M and Asundahara M. (1999): Production technology of Medicinal and Aromatic crops Natural remedies pvt Ltd. Bangalore India (26-29).

[23] Trease, G.E. and Evans, W.C (1989).Pharmacognosy.11 $11^{\text {th }}$ Edition, MacmillianPublishers, London, UK. 
Long Term Consumption of Ibie Leave (Mucuna Flagellipes) Diets Improves Visuo- Spatial Learning and Memory in Swiss White Mice

[24] Morris, R., 1984. Developments of a water-maze procedure for studying spatial learning in the rat.J.Neurosci.Methods, 11:47-60.

[25] Rendeiro, C., Guerreiro, J. D.T., Williams, C. and Spencer, J. (2012) Flavonoids as modulators of memory and learning: molecular interactions resulting in behavioral effects. Proceedings of the Nutrition Society, 71 (2). pp. 246-262. ISSN 1475-2719 doi: 10.1017/S0029665112000146.

[26] Sofowara E.A (1982): Medicinal plants and traditional medicine in Africa. New York. John Willey and sons' pp: 107-112.

Citation: A. Amah et al., "Long Term Consumption of Ibie Leave (Mucuna Flagellipes) Diets Improves VisuoSpatial Learning and Memory in Swiss White Mice", International Journal of Medicinal Plants and Natural Products (IJMPNP), vol. 4, no. 2, pp. 25-31, 2018. http://dx.doi.org/10.20431/2454-7999.0402004

Copyright: (C) 2018 Authors. This is an open-access article distributed under the terms of the Creative Commons Attribution License, which permits unrestricted use, distribution, and reproduction in any medium, provided the original author and source are credited. 